\title{
Solutions to the Advancement of Stem Cell Research
}

\author{
Sharon S. Huang ${ }^{1}$, Erick C. Huang ${ }^{1} \&$ Chao Shen Huang ${ }^{2}$ \\ ${ }^{1}$ Morrison Academy, Taichung, Taiwan \\ ${ }^{2}$ Da Chia Clinic, Taichung, Taiwan \\ Correspondence: Chao Shen Huang, Da Chia Clinic, Taichung, Taiwan. E-mail: cs2777726@gmail.com
}

Received: April 20, 2017

doi:10.5539/ass.v13n7p107
Accepted: June 1, 2017 Online Published: June 23, 2017

URL: https://doi.org/10.5539/ass.v13n7p107

\begin{abstract}
Stem cell research is a developing field of research that is both promising and exciting. Although research has greatly furthered scientists' knowledge of pathological diseases, stem cell research is not unmet with controversy. These oppositions stall the advancement of stem cell therapy and its potential to cure or save millions of people's lives, an obstacle that should be overcome for the benefit of many. Thus, to get rid of the obstacles that prohibit the advancement of stem cell research, the public should be taught the basics of stem cell research through federal funded advertisements, a research institution gathering scientist worldwide should be established outside of the US with the goal of primarily conducting stem cell research, wherever the institution is established, funding for research should not be limited to governmental funding, and finally, an international guideline for stem cell research should be established.
\end{abstract}

Keywords: stem cell research, funding, global institute, guideline, protocol

\section{Introduction}

Mention cancer, HIV/AIDS, Parkinson's, or Alzheimer's in any conversation and an ominous, fearful mood will immediately begin to dampen even the most lighthearted atmosphere. These diseases have affected the majority of the population and will continue to do so even with constant efforts from scientists to find effective cures for these diseases. However, despite the pessimism from critics that scientists will never be able to permanently eradicate the aforementioned diseases, hope has begun to rise as a particularly promising field of research has been developing. Scientists have long sought to create therapies through the use of stem cells, mainly because of the stem cell's ability to develop into any type of cell that exists in the human body, an ability that researchers call plasticity (Bellomo, 2006). This unique ability is especially exciting because scientists can coax stem cells to develop into tissues that normally are irreplaceable and develop therapies for regeneration of tissue wounds (Amarpal, Dhama, Chakraborty, \& Natesan, 2013). However, in spite of the hope that stem cell therapies could bring to the medical field, the efforts to advance such therapies are not without obstacles. Controversy surrounding the use of embryos in embryonic stem cell research has stalled the advancement of stem cell technology and has affected the amount of much needed government funding allocated for this research (Brock 2006). Furthermore, opposition from the general public, largely due to the public's unfamiliarity and misunderstanding of stem cell research, has also slowed down research. Thus, to get rid of the obstacles that prohibit the advancement of stem cell research, the public should be taught the basics of stem cell research through federal funded advertisements, a research institution gathering scientist worldwide should be established outside of the US with the goal of primarily conducting stem cell research, wherever the institution is established, funding for research should not be limited to governmental funding, and finally, an international guideline for stem cell research should be established.

\section{Methods}

\subsection{Raising Awareness}

One of the main factors that impede the advancement of stem cell research is public misunderstanding of stem cell research; this can be solved through government supported public announcements that educate people. These public information sessions can debunk common myths surrounding stem cell research. For example one common misconception about stem cell research is that all stem cell research involves the use of embryonic stem cells, which has led to great opposition from the public (Cho \& Magnus, 2007) . In reality, stem cells can be obtained through various ways such as extraction from adult bone marrow, "reprograming" a normal tissue cell, 
or through the controversial extractions of embryonic cells (Henderson, 2014). Although the most common method of harvesting stem cells in the past was through use of embryos, more and more research is being done on stem cells that have not been harvested from embryonic cells and, therefore, will not cause as much of a controversy (Henderson, 2014). If the public would have known this fact, there wouldn't be as much of an opposition towards all stem cell research. In addition, there is a wide percentage range of adults worldwide that are aware of and understand the fundamentals of stem cell research. Through a survey done by the BBVA foundation, an organization that supports researching, training, and exchanging scientific information, it was observed that, "Globally there is a great disparity in awareness of stem cells - from 33\% (Japan) to 86\% (Sweden \& Denmark) of respondents having heard of stem cells” (O’Malley, 2014). In addition, according to the same survey, "Only 34\% of adults in the United Kingdom felt that they truly know what stem cell research is according to a survey done for the United Kingdom government” (O’Malley, 2014). These statistics show that there is a large disparity in global awareness of stem cell research, and that many of the countries' general public awareness of stem cell research is not high. To combat this, governments should collaborate with stem cell experts to educate and help the public understand the basics of stem cell research through media platforms such as newspapers, radio and television announcements, social media, etc. In addition, posting advertisements on billboards to inform the public about stem cell research, or holding public debates about the pros and cons of embryonic stem cells would be helpful. Debates, in particular, can help people become aware of the benefits of stem cell research. According to surveys done by James O'Malley, a $\mathrm{PhD}$ in biomedicine at the University of Edinburgh, "Acceptance of human embryonic stem cell research was higher when potential medical benefits were made clear to respondents" (O’Malley, 2014). Through learning about the benefits and negatives by attending public debates on the ethics of stem cell research, the public can better make informed opinions about stem cell research. Other events, such as holding government funded events that are interactive information sessions about current research advancements and friendly competitions to come up with new ways of creating stem cells designed to encourage children to think innovatively could be put to use. Currently, October 14 is Stem Cell Awareness Day; its creators hoped to draw awareness to stem cell research (Stem Cell Awareness Day, 2015). Unfortunately, this day has hardly garnered any attention from the public which defeats the purpose of an awareness day when few people know of its existence. However, the public awareness of Stem Cell Awareness Day could be increased through social media platforms such as Facebook or Twitter, which would reach a young demographic and achieve the purpose of bringing awareness to a larger audience and better informing the public about stem cell research.

\subsection{Establishing Global Institutions}

An institution that would gather stem cell researchers together should be established outside of the United States. The United States has long been a leader in the general area of scientific research. However, due to great resistance from the general public that originates from stem cell controversies, stem cell research in the US has been restricted by federal laws and limited governmental funding, which does not make the US an appropriate candidate to host a centralized institution with a primary focus on stem cell research (Human embryonic stem cell, 2010). Contrarily, countries in Europe and Asia, such as the United Kingdom and Singapore, are emerging as leaders in stem cell research due to strong support from their general publics and their governments. Singapore, for example, is known as "Asia's stem cell center", a title earned from its multitude of research groups and its authorization of embryos younger than two weeks old for therapeutic purposes (Dhar \& Ho, 2009). In addition, Singapore has been actively recruiting scientists from all over the world to conduct research in its institutions (Ralston, 2008). Similarly, the United Kingdom currently hosts the world's largest stem cell bank and is one of the global leaders in research of the characterization of all the existing embryonic stem cell lines (Bellomo, 2006). Thus, a centralized institution for stem cell research should be established in countries where the research is not as controversial and met with such strong resistance. Then a big question arises. How should the host country be chosen to ensure that the institution would be built and funding would not disappear elsewhere? The choice of the host country and the recruitment of scientists should be done by the International Society for Stem Cell Research, which is a nonprofit organization comprised of stem cell experts and researchers from around the world. The appropriateness for the host country should be based on its level of stem cell restrictions, government approval, a complete set of timelines to build and provide facilities to the institution, and approval of the host country by the committee of International Society for Stem Cell Research. Once the elected host country accepts the proposition to establish an international center for research, the International Society for Stem Cell Research should enforce the timeline that was provided by the host country to make sure the institution is established in a timely order. Funding for this institution should be provided by the government of the host country and any private investors. While many would say this restriction wouldn't provide any incentive for any government to establish a research institute, it is widely believed that governments would be 
willing to carry out such plans because of the commercial promises that stem cell therapy brings.

\subsection{Funding}

The institution established should not be limited to only accepting funding from governments. Funding from private donors should be made available since one of the main factors that inhibit the rapid growth of stem cell technology is the lack of funding for research. While others would argue that stem cell research in the US and other countries is sufficiently funded by the countries' respective governments, those promised funds are usually limited by political influences and restricted by a country's economic status. An example of limitation by political influences was seen in the Bush-era. In 2001, President George W. Bush banned government funding for embryonic stem cell research and twice vetoed Congress' attempts to pass laws that allowed for obtaining stem cells from leftover embryos in fertility clinics (Adelson \& Weinberg, 2010). It was only when President Barack Obama was elected that the bans President Bush put on embryonic stem cell research were lifted (Henderson, 2014). The ban placed on funding stem cell research was a great setback for stem cell technology in the US and is a prime example of political influences that impede stem cell development. These setbacks have also aroused the fears from experts that the US is falling behind Europe, South Korea, and Singapore on stem cell research. Professor John D. Gearhart from the Johns Hopkins School of Medicine acknowledged "There is a feeling we have got to do something rapidly or we are going to be really out of the ball game” (Bellomo, 2006). On the other hand, private investors are much more motivated to invest in research due to stem cell's commercial potential in therapy, and therefore it gives researchers more freedom to test novel ideas that would otherwise be untestable under limited governmental funding. In fact, currently, most funding for stem cell research in the US come from private investors as opposed to the federal government, even though the government has pledged money to support stem cell research. According to James Fosset, the director of a stem cell research foundation called Nelson A. Rockefeller Institute of Government, "What seems most likely, in short, is that the immediate future will be like the recent past, with federal government being a relatively minor player and states and private funders continuing to carry the major funding and policy development burdens." In other words, private investors will play a large role in contributing fundings for stem cell research in the future as it had in the past. Unfortunately, in the present day, many governments have prohibited private funding towards stem cell research. By passing laws that enable private funding or eliminating bills that prohibit it, governments could enable stem cell research to be better funded; this would advance stem cell technology, and it would experience its greatest growth in many years.

\subsection{Establishing an International Protocol}

Finally, an international guideline outlining protocols of stem cell culture, guiding processes for researching novel testing methods for clinical trials, and recording all existing stem cell lines should be established. It is important to establish these protocols and guidelines for stem cell research since the processes involved are complex and delicate. Any misstep could cause severe contamination and serious outcomes; especially since stem cell research is aimed at developing therapies that can be eventually used in humans. Critics of stem cell research have long pointed to the unexpected side effects and risks that accompany stem cell therapy. Those include abnormal tissue (derived from stem cell) behavior, harmful immune responses to injected stem cells in animal models, stem cell toxicity, and some cases of tumorgenesis (International Society for Stem Cell Research, 2008). It is also suspected that there are other side effects that have yet to be discovered. Bearing such concerns in mind, a protocol should be established by the previously mentioned International Society for Stem Cell Research (ISSCR) for testing, culturing, and monitoring stem cells in research. The ISSCR has already published Guidelines for Clinical Translation of Stem Cells, a broad outline of procedures for clinical trials of stem cell therapy; however, it leaves the specific restrictions up to local regulations due to the varying degrees of regulations that are in place in different parts of the world. However, a universal guideline would better benefit research since scientists could conduct research undisturbed by public controversies about the ethics of stem cell research. Dr. Neil Hanley, a researcher and clinician who is funded by the University of Southhampton's Department of Health, agrees that it is beneficial to researchers if there's a set rule of guidelines: "Investigators are at an advantage wherever they can investigate under a sound ethical and moral legislation" (Bellomo, 2006). Furthermore, the varying restrictions in each country are a concern and result in hardships when countries collaborate together but disagree with each other's regulations for stem cell research. For example, Mexico, while flourishing in stem cell research, does not have regulations restricting stem cell research, thus drawing criticism from people around the world (Dar \& Ho, 2009). On the other hand, countries such as Germany, Austria, Finland, Greece, Portugal and the Netherlands have strict regulations in the particular field of embryonic stem cell research even to the extent of banning embryonic cell use for research (Ralston, 2008). If scientists from any of the European nations mentioned above collaborated with scientists from Mexico, it would be 
difficult for all the scientists to agree to follow the same regulations since they had agreed to research under different regulations in their home countries. Thus, global cooperation in stem cell research is extremely difficult under the current situation where there are no international standard guidelines, and each country has its own different procedures and protocols (Daley et al., 2016). In addition to international guidelines, a list recording all existing stem cell lines should be created and regularly updated by researchers during meetings that the International Stem Cell Society hosts. A list of stem cell lines would give the benefit of being up to date on recent advancements to researchers that could then enable others to build upon the advancements.

\section{Conclusions}

In conclusion, stem cell research can achieve greater progress by globally implementing the following: education of the general public in regards to the basics of stem cell research through government funded advertisements, establishment of a research institution outside of the United States that would gather scientists from around the world with the goal of primarily conducting stem cell research, allowance of funding for research that should not be limited to governmental funding, and finally, the establishment of an international guideline for stem cell research (Figure 1). Through these steps, the international community will be able to reach greater heights in stem cell technology. Although the advancement of stem cell research will not guarantee cures for debilitating diseases, stem cell discoveries continually give hope to patients with terminal illness', scientists, and the general public that the developing biomedical technology will one day conquer these malicious killers.

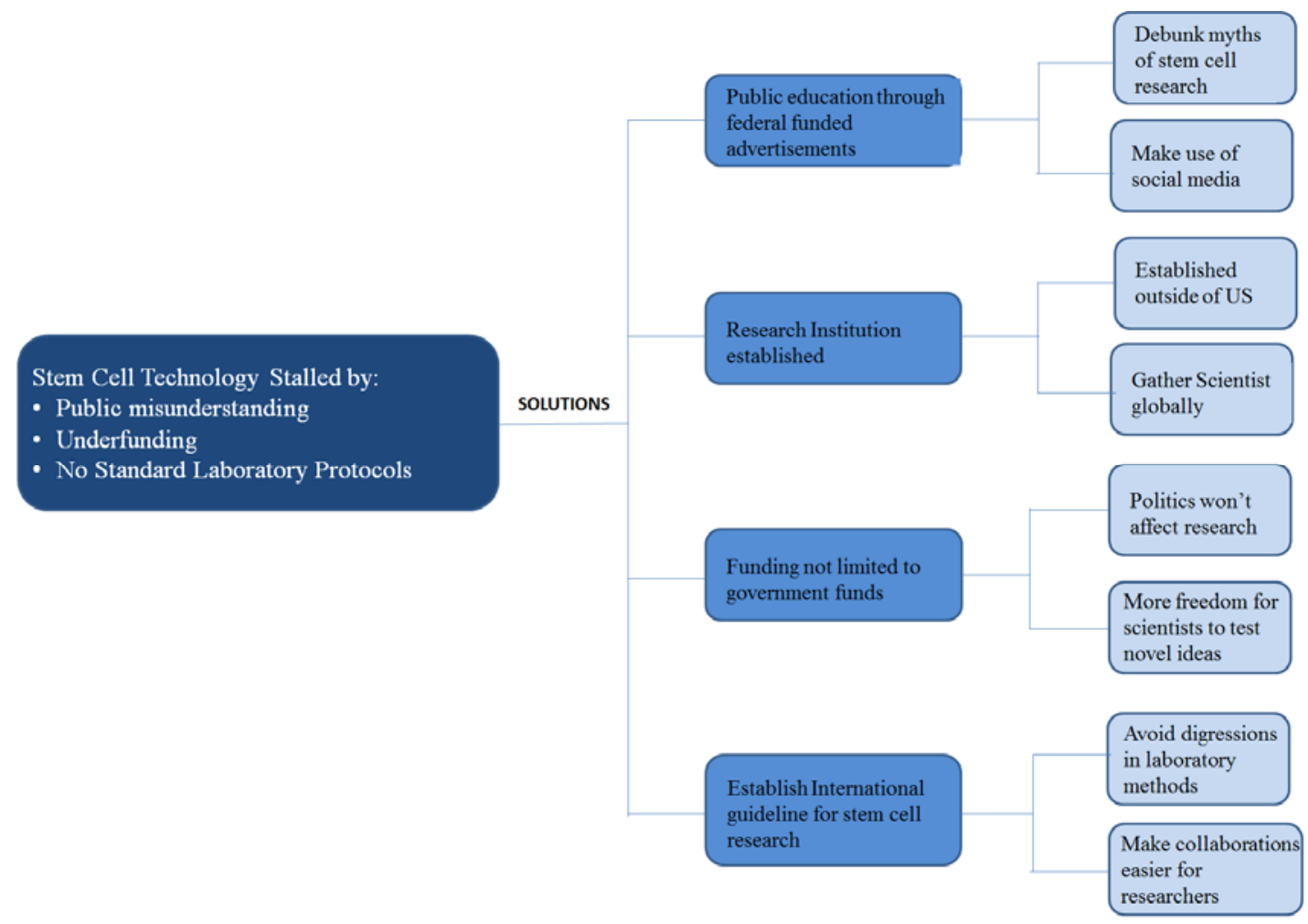

Figure 1. The overlying summary:

Stem cell technology advancement can be improved by having federal funded educational advertisements, establishing a research institution, deregulate funding to include private institutions, and establishing an international guideline for stem cell research.

\section{References}

Adelson, J. W., \& Weinberg, J. K. (2010). The California Stem Cell Initiative: Persuasion, Politics, and Public Science. American Journal of Public Health. http://dx.doi.org/10.2105/AJPH.2009.168120

Amarpal, A., Dhama, K., Chakraborty, S., \& Natesan, S. (2013). Stem cells and their clinical/therapeutic applications in biomedical and veterinary science-the perspectives. Research Opinions in Animal \& Veterinary Sciences, 3(9), 261-279.

Bellomo, M. (2006). The Stem Cell Divide: The Facts, the Fiction, and the Fear Driving the Greatest Scientific, Political, and Religious Debate of Our Time. New York, NY: American Management Association. 
Brock, D. W. (2006). Is a Consensus Possible on Stem Cell Research? Moral and Political Obstacles. Journal of Me ical Ethic. Retrieved from https://www.ncbi.nlm.nih.gov/pmc/articles/PMC2563268/. http://dx.doi.org/10.1136/jme.2005.01358

California's Stem Cell Agency (2015). Stem Cell Awareness Day, California Institute for Regenerative Medicine. Retrieved from https://www.cirm.ca.gov/our-progress/stem-cell-awareness-day

Cho M. K., \& Magnus D. (2007). Therapeutic misconception and stem cell research. Nature Reports Stem Cells. 27 Sep. Retrieved from http://www.nature.com/stemcells/2007/0709/070927/full/stemcells.2007.88.html. http://dx.doi.org/10.1038/stemcells.2007.88

Daley, G. Q., Hyun, I., Apperley, J. F., Barker, R. A., Benvenisty, N., Bredenoord A. L., ... Kimmelman, J. (2016). Setting Global Standards for Stem Cell Research and Clinical Translation: The 2016 ISSCR Guidelines. Stem Cell Reports. http://dx.doi.org/10.1016/j.stemcr.2016.05.001

Dhar, D., \& Ho, J. H. (2009). Stem Cell Research Policies around the World. Yale Journal of Biology and Medicine, 82(3), 113-115.

Fossett, J. W. (2009). States, Private Funders Will Advance Stem Cell Research. The Nelson A. Rockefeller Inistitute of Government. Retrieved from http://www.rockinst.org/observations/fossettj/2009-05-states_ private_funders_will_advance_stem_cell_research.aspx

International Society for Stem Cell Research (2008). Guidelines for the Clinical Translation of Stem Cells. Retrieved Sept. 17, 2015, from http://www.isscr.org/docs/default-source/clin-trans-guidelines/isscrglclinica ltrans.pdf

Henderson, H. (2014). Science and Technology of the 2000s. San Diego, CA: ReferencePoint Press, Inc.

Human Embryonic Stem Cell Research in the US: Time for Change? [Editorial]. (2010). Nature Cell Biology. http://dx.doi.org/10.1038/ncb0710-627

O-Malley, J. (2014). What does the public think about stem cell research. EuroStemCell. Retrieved from http://www.eurostemcell.org/faq/what-does-public-think-about-stem-cell-research

Ralston, M. (2008). Stem Cell Research Around the World. PewResearchCenter. Retrieved from http://www.pewforum.org/2008/07/17/stem-cell-research-around-the-world

\section{Copyrights}

Copyright for this article is retained by the author(s), with first publication rights granted to the journal.

This is an open-access article distributed under the terms and conditions of the Creative Commons Attribution license (http://creativecommons.org/licenses/by/4.0/). 